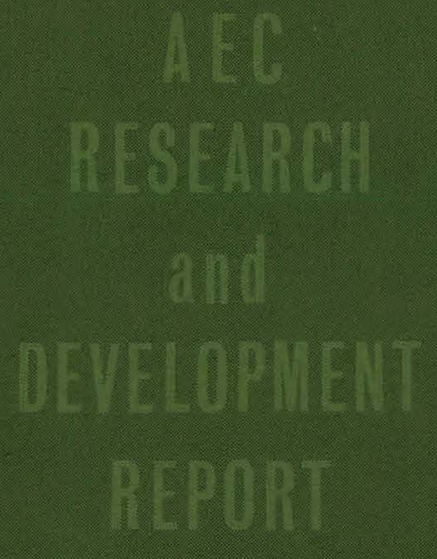

\title{
CHROMATOGRAPHIC ANALYSIS OF HELIUM CONTAINING TRACE IMPURITIES
}

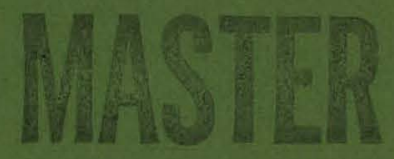

\author{
NOVEMBER, 1964
}
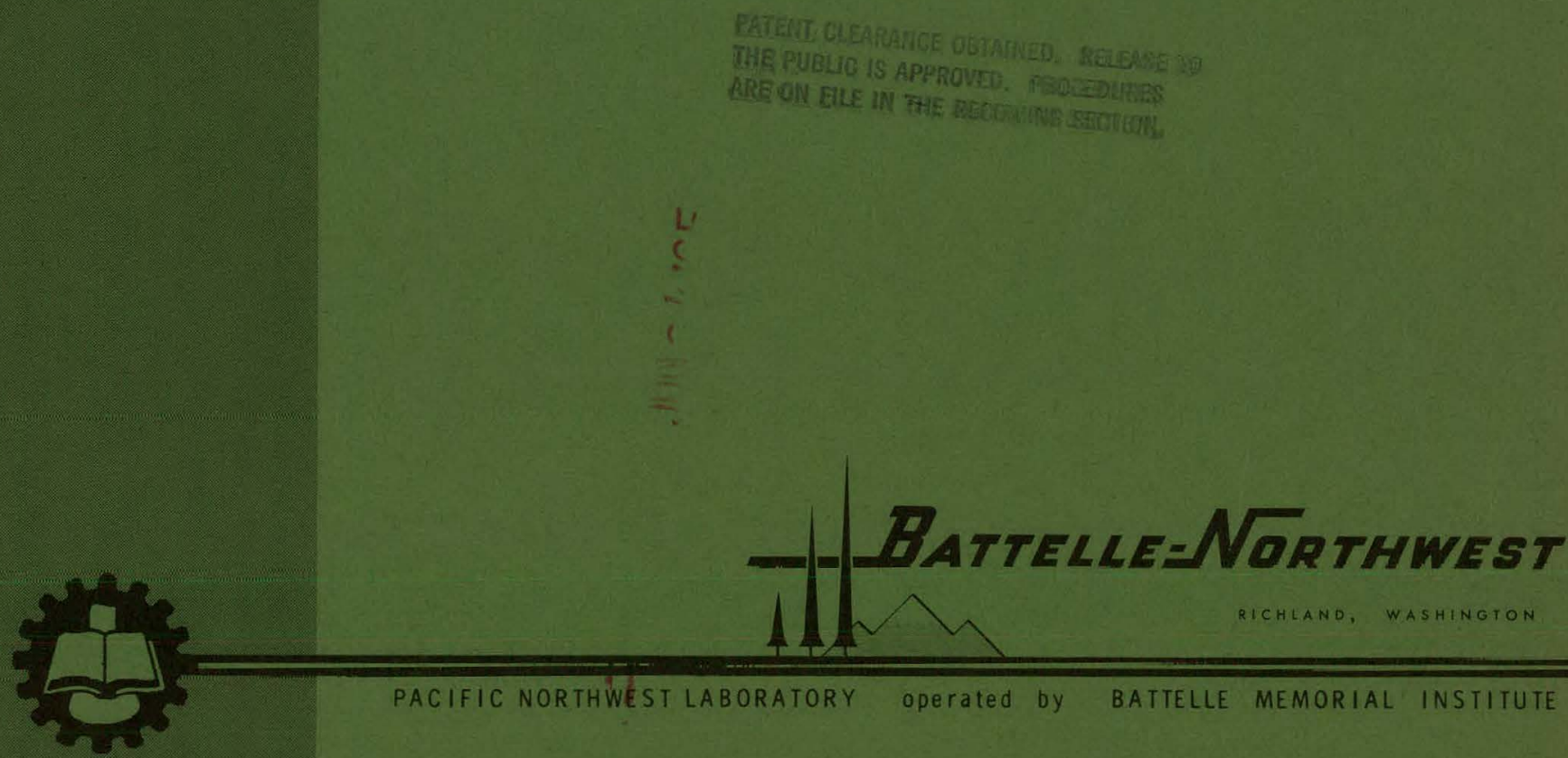


\section{DISCLAIMER}

This report was prepared as an account of work sponsored by an agency of the United States Government. Neither the United States Government nor any agency Thereof, nor any of their employees, makes any warranty, express or implied, or assumes any legal liability or responsibility for the accuracy, completeness, or usefulness of any information, apparatus, product, or process disclosed, or represents that its use would not infringe privately owned rights. Reference herein to any specific commercial product, process, or service by trade name, trademark, manufacturer, or otherwise does not necessarily constitute or imply its endorsement, recommendation, or favoring by the United States Government or any agency thereof. The views and opinions of authors expressed herein do not necessarily state or reflect those of the United States Government or any agency thereof. 


\section{DISCLAIMER}

Portions of this document may be illegible in electronic image products. Images are produced from the best available original document. 


\section{LEGAL NOTICE}

This report was prepared as an account of Government sponsored work. Neither the United States, nor the Commission, nor any person acting on behalf of the Commission:

A. Makes any warranty or representation, expressed or implied, with respect to the accuracy, completeness, or usefulness of the information contained in this report, or that the use of any intormation, apparatus, method, or process disclosed in this report may not infringe privately owned rights; or

B. Assumes any liabilities with respect to the use of, or for damages resulting from the use of any information, apparatus, method, or process disclosed in this report.

As used in the above, "person acting on behalf of the Commission" includes any employee or contractor of the Commission, or employee of such contractor, to the extent that such employee or contractor of the Commission, or employee of such contractor prepares, disseminates, or provides access to, any information pursuant to his employment or contract with the Commission, or his employment with such contractor.

\section{PACIFIC NORTHWEST LABORATORY}

RICHLAND, WASHINGTON

Operated By

BATTELLE MEMORIAL INSTITUTE

For The

U. S. ATOMIC ENERGY COMMISSION Under Contract No. AT(45-1)-1830 


\section{CHROMATOGRAPHIC ANALYSIS OF HELIUM} CONTAINING TRACE IMPURITIES

$$
\text { By }
$$

D. W. Shannon

Metallurgy Research

Reactor and Materials Technology

November, 1964

PACIFIC NORTHWEST LABORATORY

RICHLAND, WASHINGTON 


\section{CHROMATOGRAPHIC ANALYSIS OF HELIUM CONTAINING TRACE IMPURITIES}

\section{INTRODUCTION}

A high temperature helium gas loop is to be built in the Advanced Test Reactor near Idaho Falls, Idaho. This loop will be used to study irradiation effects on construction materials at temperatures up to $1300 \mathrm{C}$. Exposure of metals to gas at these temperatures requires very pure helium. In turn, the helium purity requires highly sensitive analytical instruments. Sensitive gas chromatographic instruments offer a good combination of high sensitivity, mechanical reliability, and moderate initial cost. Probable impurities in the helium are hydrogen, oxygen, nitrogen, mèthane, carbon monoxide, carbon dioxide, and water vapor.

Gas chromatographs using thermal conductivity detectors have had difficulties in achieving high sensitivity for hydrogen when a helium is used as a carrier because of the similar thermal conductivities of helium and hydrogen. 'Using argon as a carrier, two chromatographs and a complicated $\mathrm{H}_{2}-\mathrm{He}$ separation are required.

It has been reported that a beta ionization detector, using a helium carrier, ${ }^{(1,2)}$ is capable of high sensitivity if very pure helium is used. The purpose of this work was to develop the beta ionization concept to the analysis of trace impurities in helium.

\section{SUMMARY AND CONCLUSIONS}

A gas chromatograph has been developed that has a lower detection limit of below $1 \mathrm{ppm}$ for hydrogen, oxygen, nitrogen, methane, carbon monoxide, and carbon dioxide. The instrument can detcct neon, argon, krypton, and zenon; argon and oxygen interfere with each other.

This chromatograph uses a tritium source ionization detector. When used with ultrapure helium carrier gas this device functions as an extremely sensitive "helium" detector using the metastable helium 
atoms to increase response at low ppm levels. Construction and operating details are discussed and a modification is shown that permits total impurity analysis of helium with sensitivities below $1 \mathrm{ppm}$.

\section{EQUIPMENT}

Detector

The detector chosen for this work is the microion cross section detector described by Lovelock. ${ }^{(3)}$ The detector uses $260 \mathrm{mCi}$ of tritium deposited on titanium or zirconium coated stainless steel electrodes. Ultrapure helium is used as a carrier gas. Used in this manner the detector becomes a "helium" detector similar in principle to the commonly used argon detector. Very high sensitivity is possible but response factors fluctuate with helium purity. (4). The high sensitivity results because of the ease by which helium metastables generated in the radiation field can ionize: the species to be detected (all impurities except neon have lower ionization potentials). The concentration of helium metastables at any time is an equilibrium between a constant rate of formation and the rate of destruction by interactions with carrier impurities or eluted species. Sensitivity is lost to the extent that carrier gas impurities reduce the concentration of helium metastables. To obtain satisfactory and reproducible response, the system must be extremely leak-tight, the carrier gas ultrapure, and column bleed-off held constant.

Columns

The two columns were $1 / 8$-in. -OD stainless steel tubing packed with $30 / 60$ mesh $13 \mathrm{X}$ molecular sieve (for $\mathrm{H}_{2}, 0_{2}, \mathrm{~N}_{2}, \mathrm{CH}_{4}, \mathrm{Xe}, " \mathrm{Kr}$, Ar, $\mathrm{Ne}$ ) or $30 / 60$ mesh silica gel (for $\mathrm{CO}_{2}$ ). The $13 \mathrm{X}$ molecular sieve produced sharper peaks than $5 \mathrm{~A}$ molecular sieve resulting in increased sensitivity. The molecular sieve column was $6^{-} \mathrm{ft}$ long and the silica gel column $3 \mathrm{ft}$ long. A small piece of glass wool was inserted in each end to hold the packing in place. The ends of the $1 / 8-i n$. SS tubing were filled with a piece of No. 14 nichrome wire to reduce the dead 
volume. The packed section of tube was placed in a $600 \mathrm{Ml}$ Glascol heater for activation. The columns were activated and periodically cleaned by heating to $150 \mathrm{C}$ for 3 or $4 \mathrm{hr}$ while flushing with ultrapure helium. It was found that heating over $200 \mathrm{C}$ increased elution times too much for sharp resolution of trace impurities. It was also noted that traces of oxygen could not be eluted off of $5 \mathrm{~A}$ molecular sieve at $75 \mathrm{C}$ but seemed to be absorbed. After activation the column had to be saturated with oxygen before a trace oxygen analysis could be run. The columns were operated at room temperature to minimize bleed-off contamination.

\section{Piping Arrangement}

This work started with a commercially available chromatograph. It was soon found that leaks in the detector, valves, and piping rendered the instrument unsuitable for trace level analysis, expecially for oxygen and nitrogen. A new chromatograph was constructed with the detector, valves, columns and all piping in a helium filled box (Figure l).

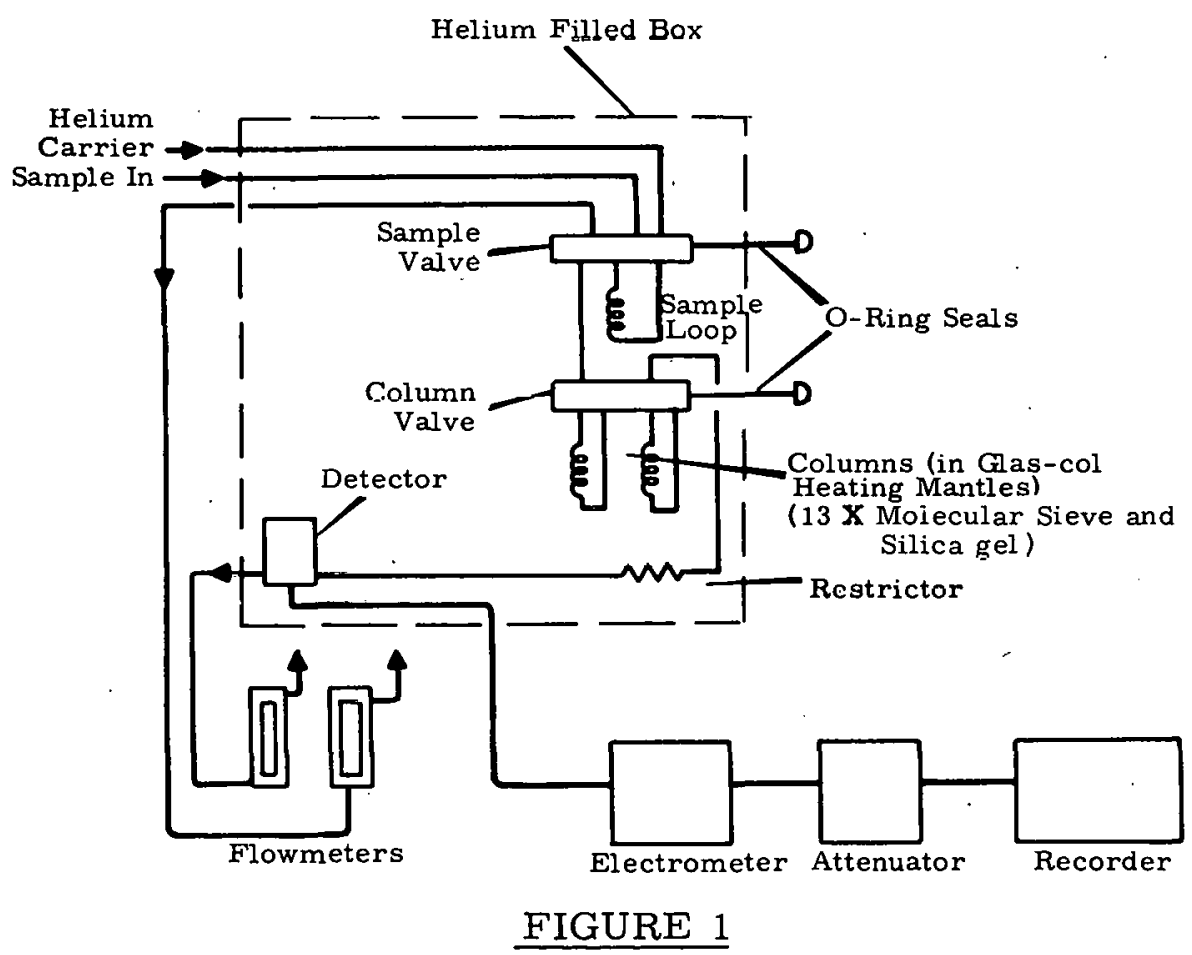

Schematic of Chromatograph 
The original plug-type valves were replaced by linear O-ring valves. However, even the O-ring valves had detectable air inleakage when operated in air. The detector was modified with O-rings to make the housing more leak-tight and all electrical fittings were brought into the box through a sealed fitting. The valve stems were brought through the box with a highvacuum $O-R i n g$ fitting. Placing all the critical components in the helium atmosphere reduced air leaks to below detectable levels.

The sample loop was a 24-in. piece of 1/8-in. -diameter stainless steel tubing and had a volume of about $2.7 \mathrm{~cm}^{3}$.

\section{Electrical Wiring}

The electrometer from the original chromatogr"aplı was used although the rechargeable batteries caused some inconvenience. Since this type of detector has a fairly high noise level (approximately $10^{-13}$ amps) any good quality chromatographic electrometer would be suitable. The only special wiring requirement is careful shielding of the leads between the detector and electrumeter. These leads are vibration sensitive and the shielded cable was enclosed in a copper tube conduit for rigidity and additional shielding.

The output of the elechrometer was run through an automatic attenuator to a 0-1 millivolt potentiometric recorder.

\section{PROCEDURES}

\section{Operating Parameters}

The beta ionization detector is rather insensitive to temperature and pressure changes so that no special use of thermostats was required for intermittent chromatography. However, for an automatic process stream instrument a constant temperature would be desireable to minimize base line drift.

The carrier gas pressure at the inlet was $50 \mathrm{psi}$. This made possible a helium flow rate of $150 \mathrm{cc} / \mathrm{min}$ through the molecular sieve column and $200 \mathrm{cc} / \mathrm{min}$ through the silica gel column. It is desirable to elute the peaks as rapidly as consistant with complete separation. 
The longer the impurity components remain on the column, the more random diffusion broadens the peak. This effect has been recently demonstrated by Kargor and Cooke.

The carrier gas used was obtained from Matheson Corp. as

"ultrapure" helium. A typical analysis is given in Table I. This gas has a total impurity of 14 ppm including 11 ppm neon.

Choice of Columns

Either the molecular sieve column or the silica gel column is selected by a column switch valve (Figure.1). This method was chosen in preference to arranging the two columns in series. If the silica gel column is placed ahead of the molecular sieve column the transit time of $\mathrm{H}_{2}, \mathrm{O}_{2}, \mathrm{~N}_{2}, \mathrm{CH}_{4}$, and $\mathrm{CO}$ is increased and sensitivity is reduced. Also when the silica gel column is switched directly to the detector the higher bleed-off rate of silica gel causes a severe base line shift for about $15 \mathrm{~min}$. It was preferable to switch the columns and wait until the bleed-off stabilized rather than attempting a two-column separation. These base-line problems were most severe when detecting samples at low ppm levels.

\section{Operating Procedure}

The quantity of sample gas was unlimited for this work and was piped from a manifold where êther standard gas or unknown gas could be selected. After the sample loop was purged the sample was injected into the instrument by using the gas sample valve. The output of the detector appeared as successive peaks on the recorder. Automatic attenuation was used to keep the peaks on scale. However, some difficulty was encountered with the hydrogen peak that was so sharp that the response time of the automatic attenuator was insufficient. Manual attenuation was then used. Automatic integration was not found to be necessary. 


\section{Calibration}

The peak heights of the various impurities to be measured were calibrated against known standards. These standards were prepared in the facility shown in Figure 2. A stainless steel gas cylinder was evacuated to below $1 \mathrm{\mu}$. Impurity gases were then added as measured with a mercury manometer or Mcleod gauge accurate to about $\pm 1 \%$. Helium was then added to a total pressure of approximately 1000 psi as measured on a precision pressure gauge. Both the standard gas and the

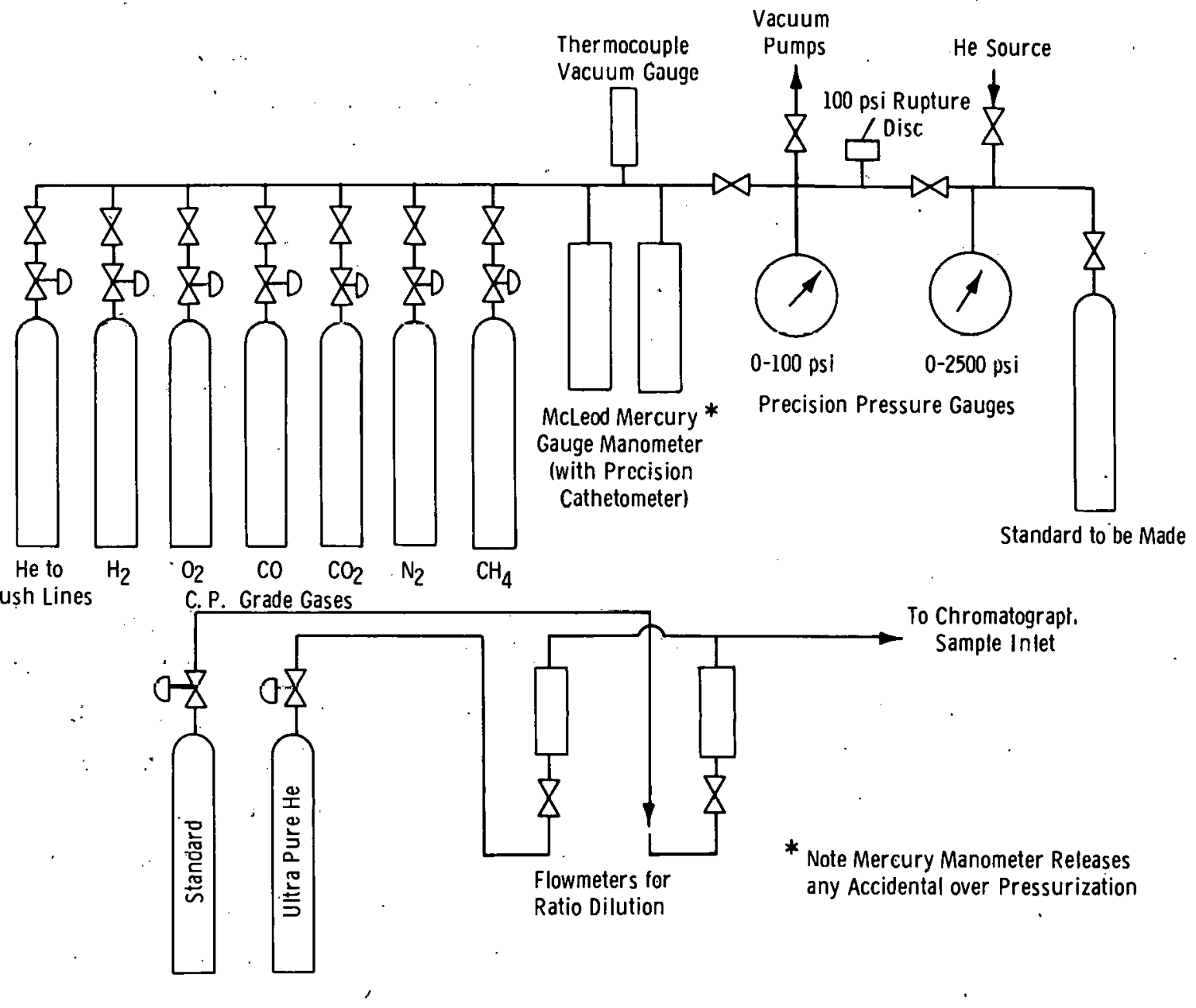

FIGURE 2

Schematic of Facility for Make-up of Standard Gases 
makeup helium were analyzed on the chromatograph and the results corrected for the original impurities in the helium. Typical calibration mixtures are given in Table I. To provide more dilute mixtures, standards were blended with ultrapure helium (Table II) in ratios $10 / 1,5 / 5$, $2 / 10$, etc. Dilution of primary standards to overlap the next lower mixture provides a method for intercomparison of mixtures.

TABLE I .

CUMPOSITION OF GAS STANDARDS

\begin{tabular}{|c|c|c|c|c|c|c|c|c|}
\hline \multirow[b]{2}{*}{ - } & \multicolumn{3}{|c|}{ Standard 1 } & \multicolumn{3}{|c|}{ Standard 2} & \multicolumn{2}{|c|}{ Standard 3} \\
\hline & $\begin{array}{l}\text { Partial } \\
\text { Pressure, } \\
\text { Torr } \\
\end{array}$ & $\begin{array}{c}\text { ppm } \\
\text { Added } \\
\end{array}$ & $\begin{array}{l}\text { ppm } \\
\text { Total }\end{array}$ & $\begin{array}{l}\text { Partial } \\
\text { Pressure, } \\
\text { Torr }\end{array}$ & $\begin{array}{c}\text { ppm } \\
\text { Added }\end{array}$ & $\begin{array}{l}\text { ppm } \\
\text { Total }\end{array}$ & $\begin{array}{l}\text { Partial } \\
\text { Pressure, } \\
\text { Torr }\end{array}$ & $\begin{array}{l}\text { ppm } \\
\text { Total }\end{array}$ \\
\hline $\mathrm{H}_{2}$ & 1.96 & 78 & 78 & 0.227 & 4.6 & 4.6 & 21.7 & 868 \\
\hline $\mathrm{O}_{2}$ & 0.43 & 17 & 18 & 0.0242 & 0.5 & 1.9 & 5.58 & 223 \\
\hline $\mathbf{N}_{2}$ & 1.71 & 68 & 74 & 0.0768 & 1.4 & 7.4 & 22.3 & 852 \\
\hline $\mathrm{CH}_{4}$ & 0.89 & 36 & 36 & 0.0810 & 1.6 & 1.7 & --- & --- \\
\hline $\mathrm{CO}$ & 2.63 & 105 & 105 & 0.141 & 2.8 & 2.8 & 18.0 & 720 \\
\hline $\mathrm{CO}_{2}$ & 1.64 & 65 & 65 & -- & -- & --- & 21.0 & 840 \\
\hline $\mathrm{He}$ & $\begin{array}{l}491 \text { psi } x \\
\times 0.981 *\end{array}$ & $\begin{array}{l}51.91 * \\
=25,000\end{array}$ & Torr & $\begin{array}{l}991 \text { psi } x \\
\times 0.965=\end{array}$ & $\begin{array}{l}1.91 \\
9,642 \mathrm{~T}\end{array}$ & & $\begin{array}{r}491 \text { psi } \\
\times 0.981\end{array}$ & $\begin{array}{l}51.91 \\
=25,000 \text { Torr }\end{array}$ \\
\hline
\end{tabular}

TABLE II

COMPOSITION OF ULTRAPURE HELIUM (Vender's Analysis)

\begin{tabular}{|c|c|}
\hline $\mathrm{CO}_{2}$ & $0.1 \mathrm{ppm}$ \\
\hline $\mathrm{O}_{2}$ & 0.1 \\
\hline $\mathrm{H}_{2}$ & 0.2 \\
\hline $\mathrm{N}_{2}$ & 0.3 \\
\hline Ar & 0.0 \\
\hline $\mathrm{CH}_{4}$ & 0.0 \\
\hline $\mathrm{H}_{2} \mathrm{O}$ & 2.9 \\
\hline $\mathrm{Ne}$ & 10.9 \\
\hline
\end{tabular}




\section{RESULTS}

\section{Calibrations--Lower Detection Limit}

The results of the calibration runs are given in Figure 3 .

Assuming that a peak twice the noise level was detectable, the lower detection limits were extrapolated as given in Table III. All components are detectable below $1 \mathrm{ppm}$ and oxygen and methane approach a $0.1 \mathrm{ppm}$ detection limit. It should be emphasized that these results are for the chromatograph as a whole, rather than just detector sensitivity, and the results were obtained with actual helium gas samples.

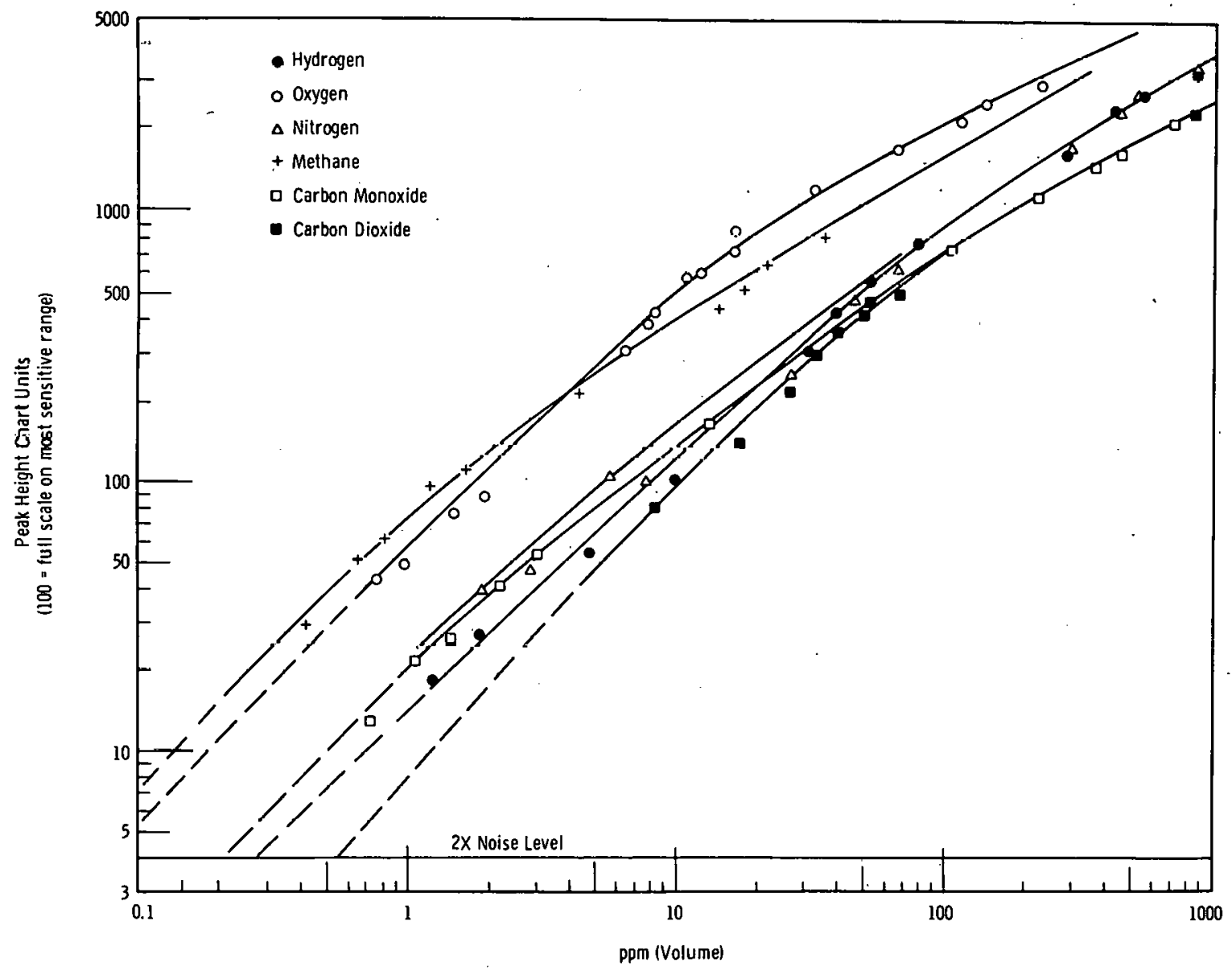

FIGURE 3

Typical Calibration Curve 


\section{LOWER DETECTION LIMITS OF IMPURITIES IN HELIUM}

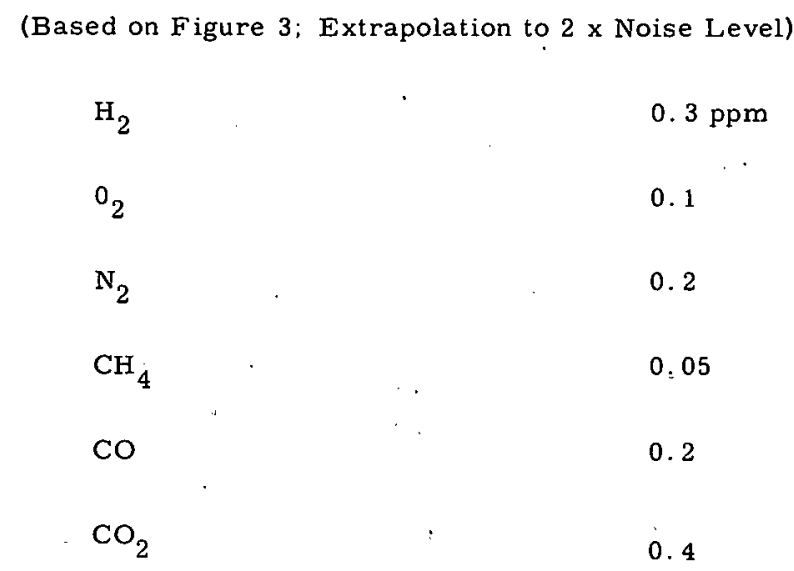

\section{Typical Chromatograms}

Typical chromatograms for various impurities are given in Figures 4 and 5 . Sharp separations were obtained even at a few ppm. Typical elution times are given in Table IV.

TABLE IV

\section{TYPICAL ELUTION TIMES}

At Room Temperature Off of Column Is ing 30/60 $13 \mathrm{X}$ Molecular Sieve (Length-6 ft, Diameter $-1 / 8 \mathrm{in}$, Flow $-150 \mathrm{ml} / \mathrm{min}$ )

\begin{tabular}{|c|c|c|c|c|}
\hline $\mathrm{Ne}$ & & $11 \mathrm{sec}$ & $\mathrm{Kr}$ & \\
\hline $\mathrm{H}_{2}$ & . & 16 & $\mathrm{CH}_{4}$ & \\
\hline $\mathrm{O}_{2}$ & . & 24 & $\mathrm{CO}$ & 1 \\
\hline Ar & $\cdot$ & 23 & $\mathrm{Xe}$ & .21 \\
\hline $\mathrm{N}_{2}$ & & $\begin{aligned} & 41 \\
. & \end{aligned}$ & & \\
\hline & $\begin{array}{r}\text { At Room } \\
\text { (Length-3 ft, }\end{array}$ & $\begin{array}{c}\text { Temper } \\
\text { Diamet }\end{array}$ & $\begin{array}{l}\text { f Silic } \\
\text {, Flov }\end{array}$ & $\begin{array}{l}m n \\
\text { min) }\end{array}$ \\
\hline$\cdot$ &. & $\mathrm{CO}_{2}$ & $100 \mathrm{~s}$ & \\
\hline
\end{tabular}

\section{Response to Noble Gases}

The elution times for neon, argon, krypton, and xenon were determined (Figure 6) and a re also given in Table IV. Neon elutes just before hydrogen; the argon peak is coincident with oxygen; krypton elutes just after nitrogen and xenon causes no interference, eluting far after carbon monoxide. 


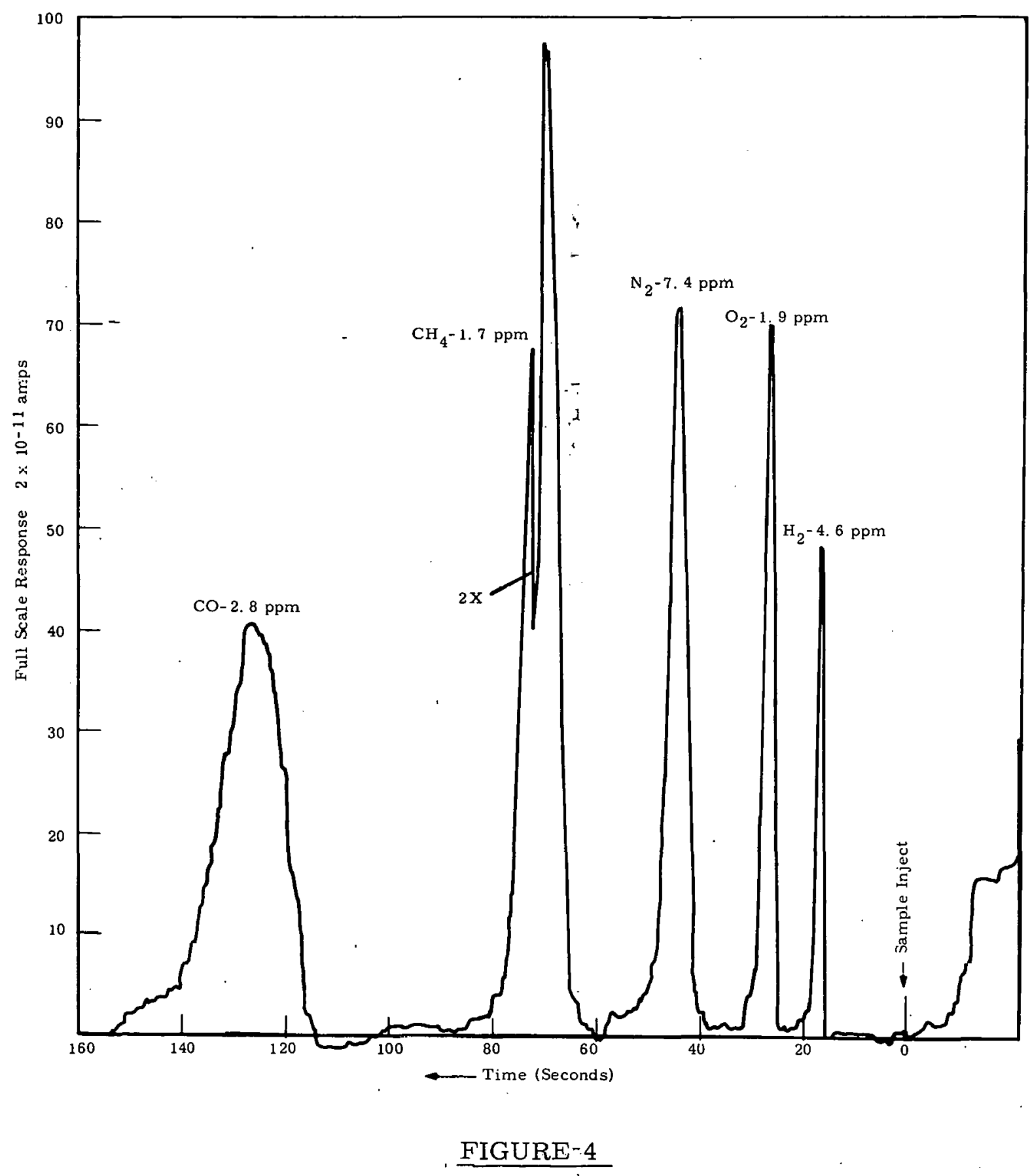

Typical Chromatogram of Impürities Added to Helium

6 ft Molecular Sieve (13X) Colúmn, Room Temperature 


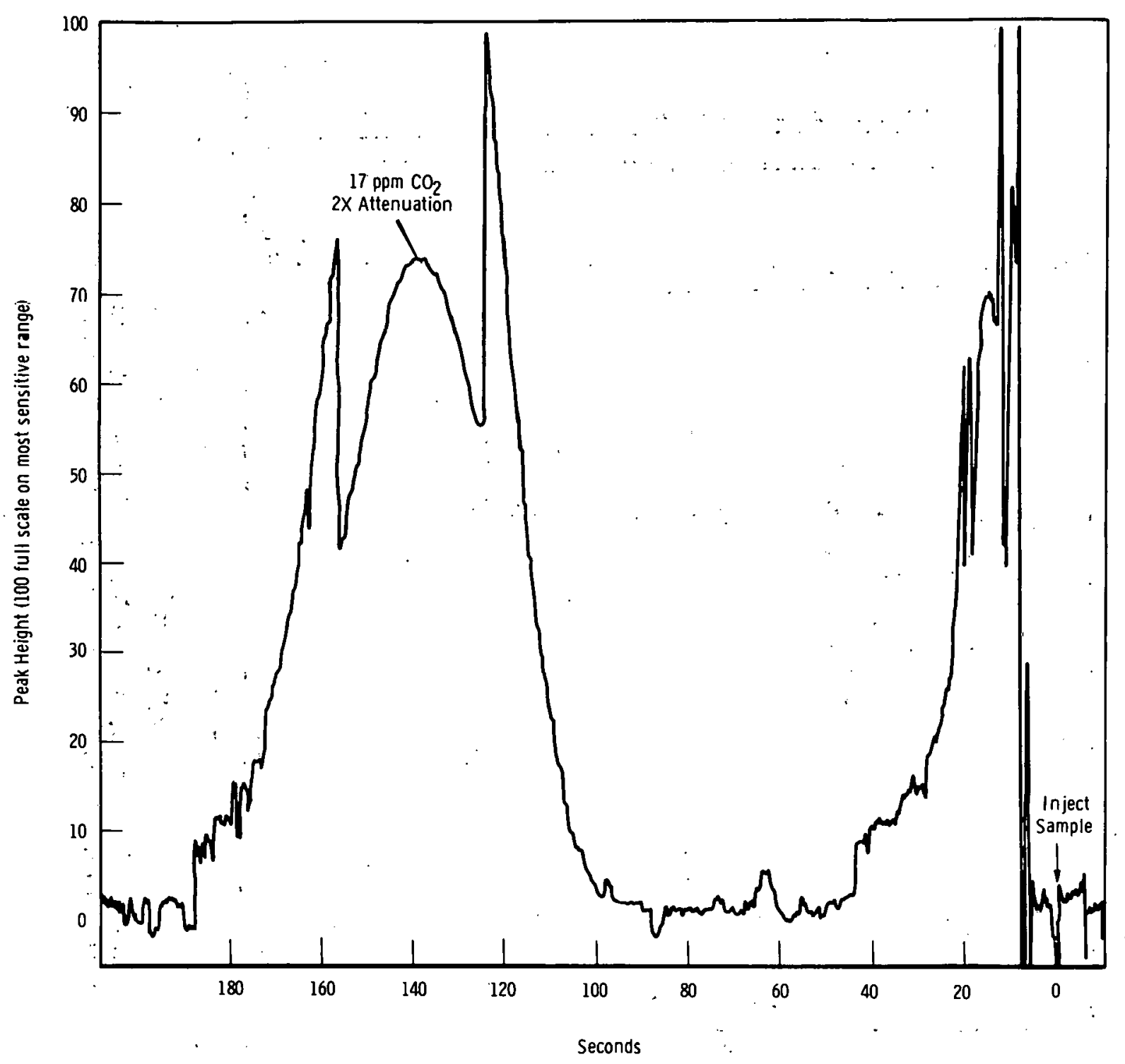

FIGURE 5

Typical Chromatogram of $\mathrm{CO}_{2} 3 \mathrm{ft}$ Silica Gel Column at Room Temperature 


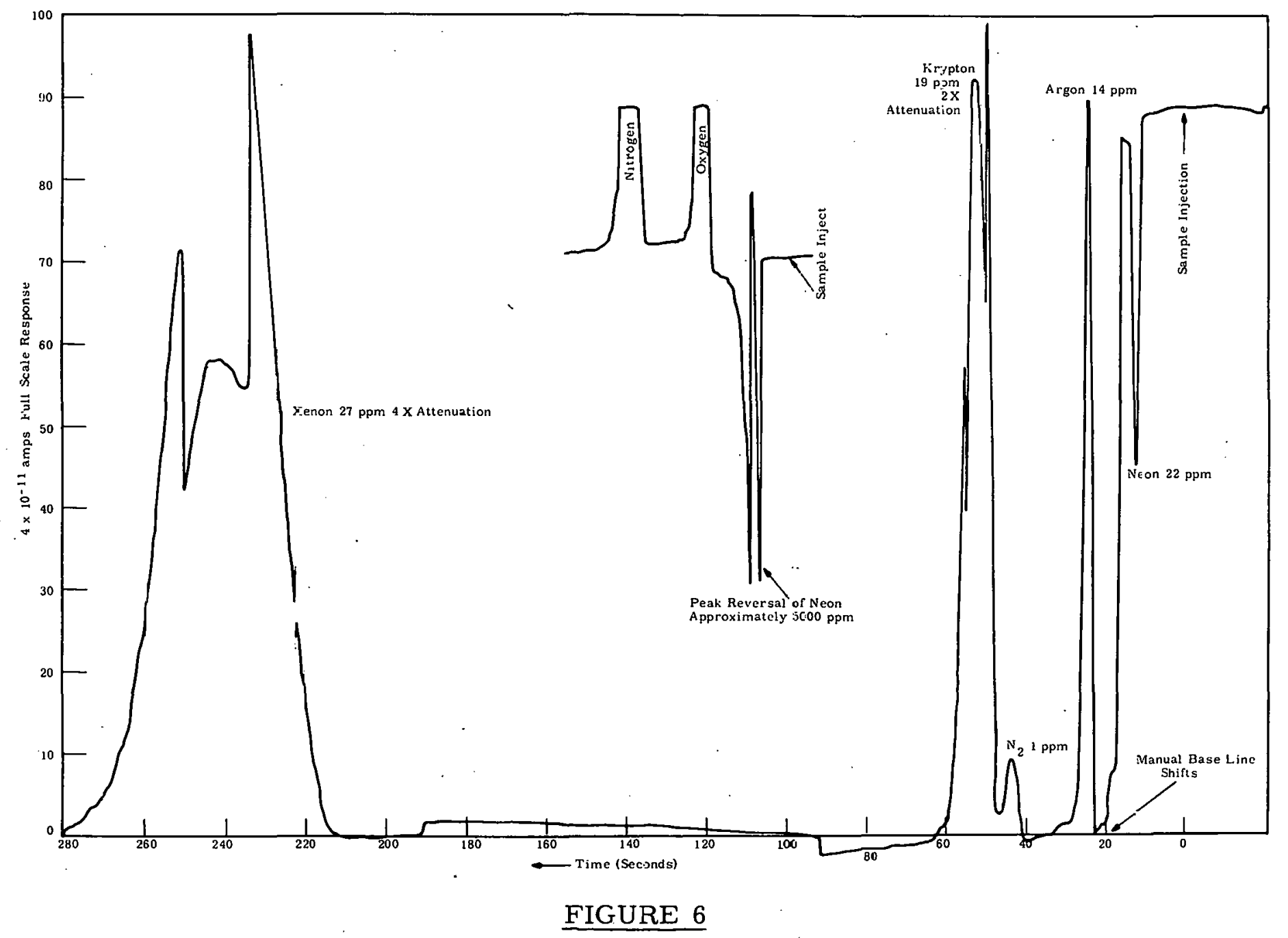

Iypical Chromatogram of Noble Gases in Helium

$6 \mathrm{ft}$ Molecular Sieve (13X) Column, Room Temperature 
The neon peak is negative because the neon ionization potential is . higher than metastable helium (Figure.6). A peak reversal occurs at high neon concentrations (Figure 6) probably because of offsetting effects of: ... depression of the base line caused by the higher ionization potential of neon and the positive peak from direct ionization of neon.

\section{Linearity of Response}

The response of the chromatographs was checked for linearity by the dilution method described. Results (Figure 7) indicate reasonable linearity up to about 20-100 ppm. As concentrations increase further.

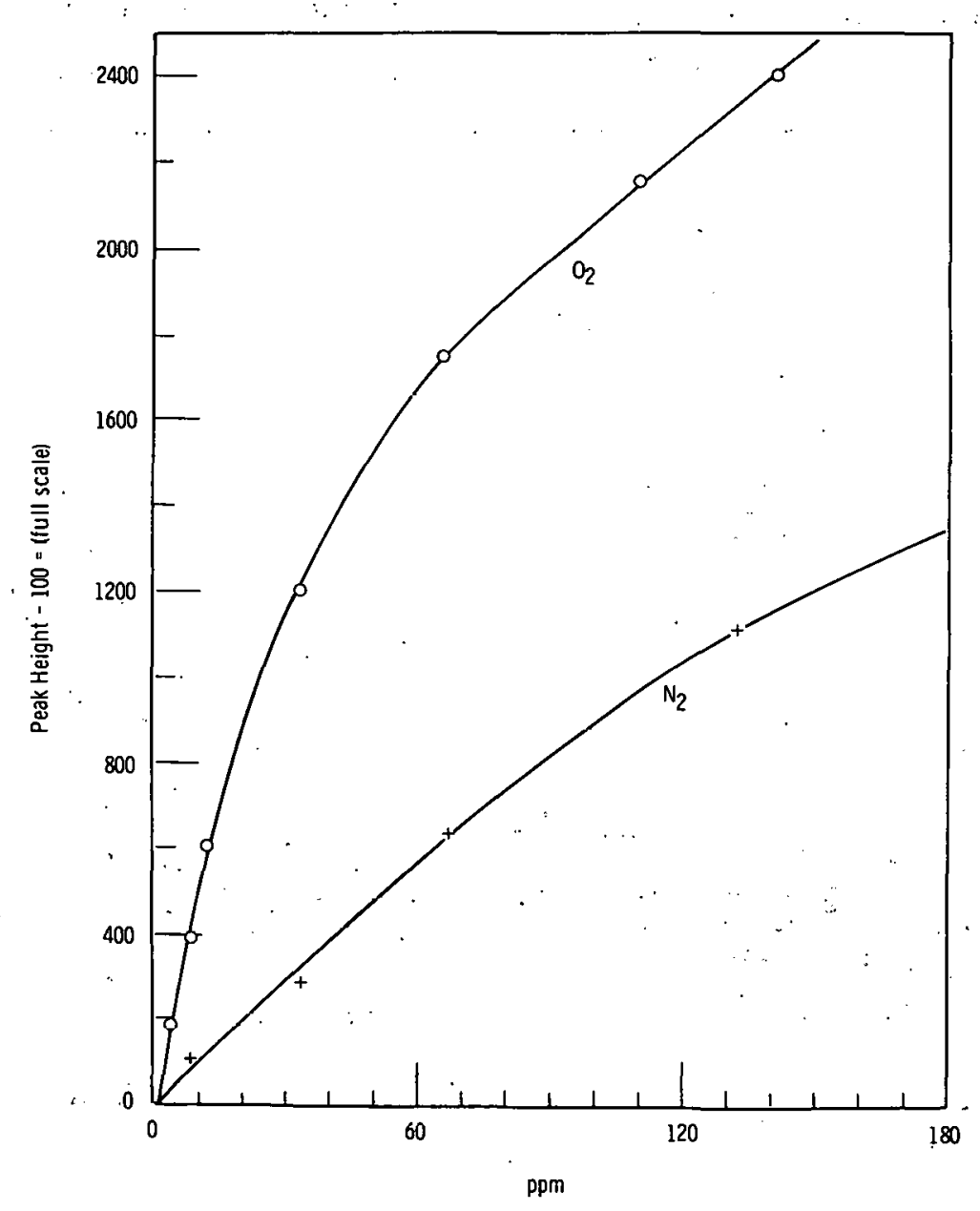

FIGURE 7

Linearity of Oxygen and Nitrogen Peak Height 
The relative response per ppm decreases and establishes a new linear relationship between 100 and $1000 \mathrm{ppm}$. This nonlinearity is to be expected with this type of detector, because in the low ppm region the response is the result of the helium metastable reaction plus direct ionization. At higher concentrations the sample impurity itself suppresses the metastables leaving only direct ionization.

\section{Detector Voltage}

A $671 / 2$ v battery was used for collector voltage in all this work. The effect of varying detector collector plate voltage on response factors was determined as shown in Figure 8 . These results indicated response was independent of collector voltage over the range of 40 to $100 \mathrm{v}$.

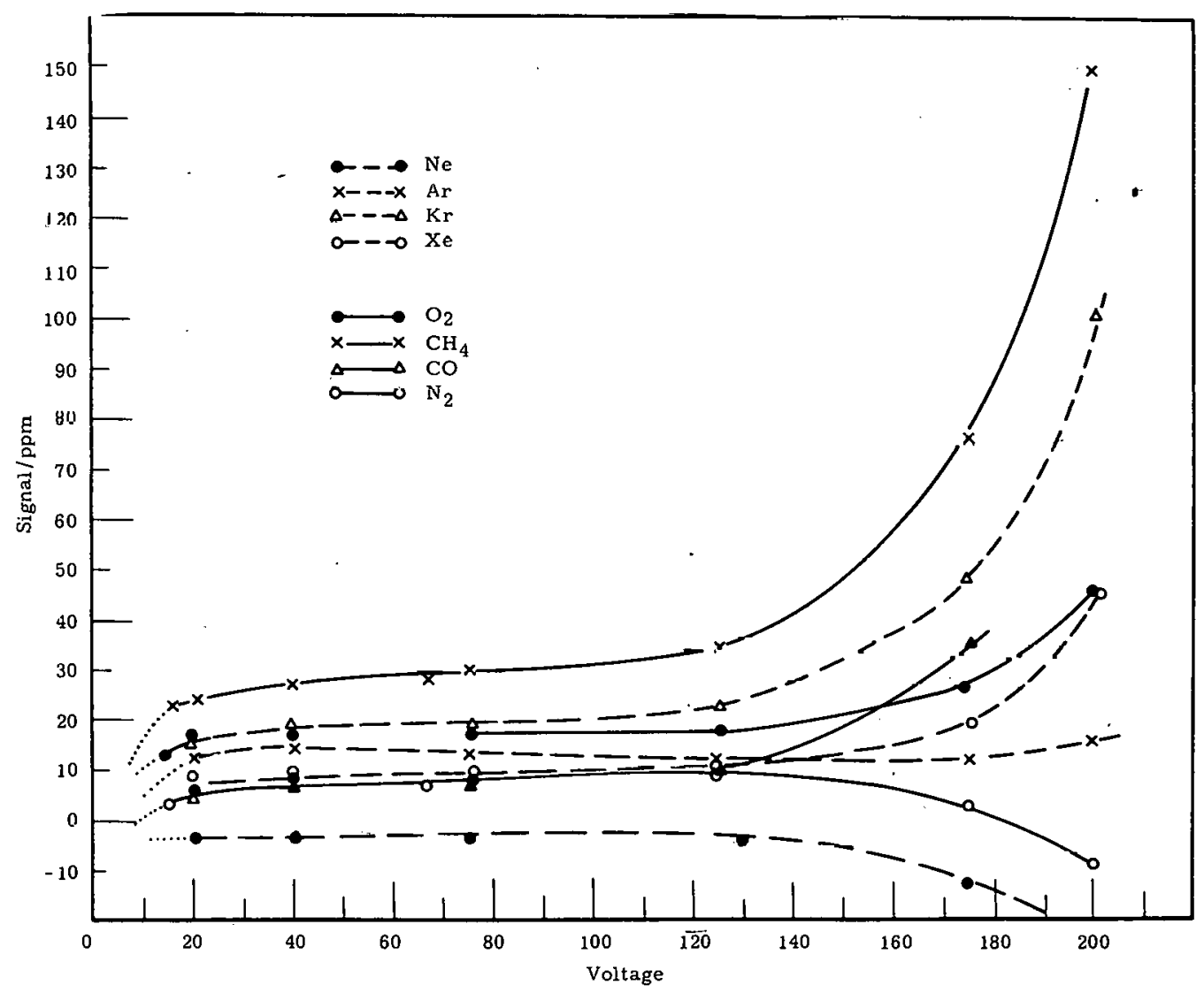

FIGURE 8

Relative Detector Response as a Function of Detector Volta'ge 
Around 200 v both response and noise:began to increase rapidly.: It:ap-. peared that the signal-to-noise ratio for oxygen was especially enhanced. However, for other components such as nitrogen the ratio was less favor - : able. The difference in response factors versus voltage was thought to offer a means of analyzing oxygen in the presence of argon. This was tried, but initial results were unsuccessful because of extreme variability and unstable response at $200 \mathrm{v}$.

TOTAL IMPURITY ANA LYZER

The changes in background current produced by variations in carrier gas purity suggest application of the detector as a total impurity analyzer of extremely high sensitivity. There is a need for such a device in the ATR Gas Loop to continuously monitor gas purity and give an . immediate alarm if purity changes for any reason. Such a total impurity analyzer can be built as shown in Figure 9 .

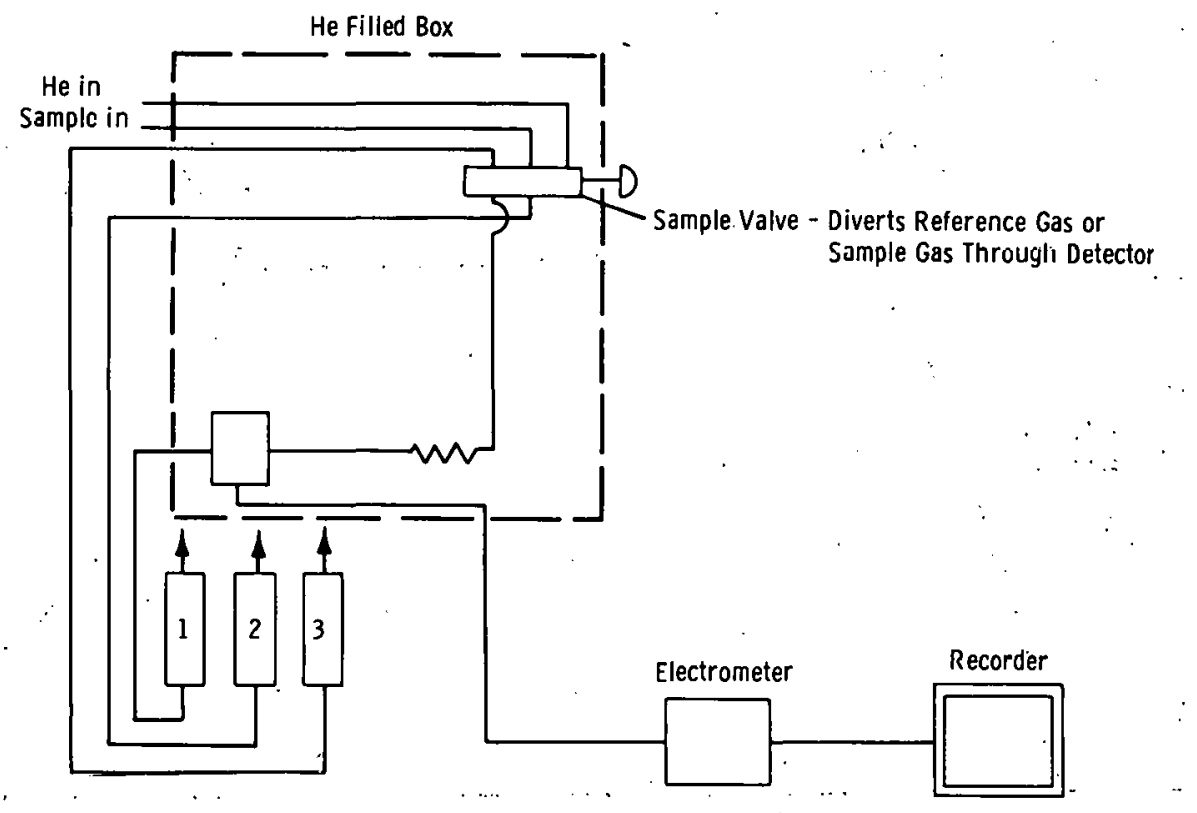

1. Detector Flow

2. Ultra Pure He Reference Flow (Indicates While Sample Flows Through Detector)

3. Sample Flow (Indicates While Reference Flows Through Detector)

FIGURE 9

Schematic of Total Impurity Analyzer 
Tests showed the feasibility of using this detector as a total impurity analyzer. Contaminated helium produced the response in Figure 10. The analyzer is sensitive to less than 1 ppm change in gas purity. An additional advantage is gained over thermal conductivity total impurity analyzers in that hydrogen produces a positive response with the ionization detector, whereas hydrogen cancels some of the response in thermal conductivity detectors.

\section{ACKNOWLEDGMENT}

The author would like to acknowledge the able assistance of G. W. Mettler in the construction, operation and calibration of the chromatograph described in this work.

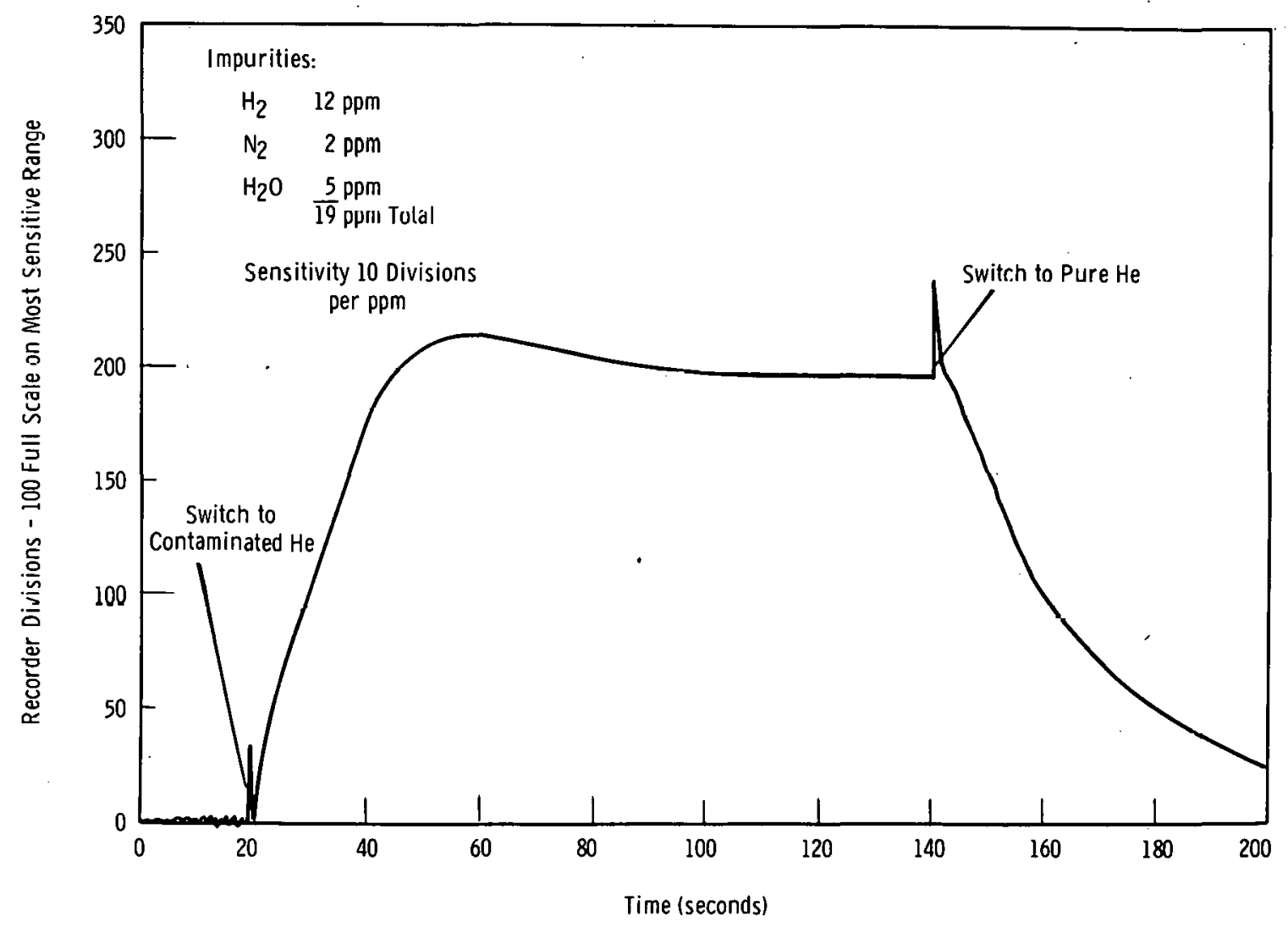

FIGURE 10

Response of Total Impurity Analyzer

to Contaminated Helium 


\section{REFERENCES}

1. J. Serpenet. J. Anal. Chem. Acta., vol. 25. p. 505. 1961

2. W. A. Wiseman. Nature, vol. 192, p. 964. 1961.

3. J. E. Lovelock, C. R. Shoemaker, and G. R. A. Zlatks. Analytical Chemistry, vol. 35, p. 460. April 1963.

4. J. E. Lovelock. Unpublished Data. Personal Communication.

5. B. L. Karger and.W. D. Cook. Analytical Chemistry, vol. 36, p. 985. May 1964. 


\section{INTERNAL DISTRIBUTION}

Copy Number

$\begin{array}{ll}1 & \text { F. W. Albaugh } \\ 2 & \text { E. R. Astley } \\ 3 & \text { J. A. Ayres } \\ 4 & \text { A. L. Bement-T. T. Claudson } \\ 5 & \text { T. K. Bierlein } \\ 6 & \text { J. J. Cadwell } \\ 7 & \text { E. W. Christopherson-H. A. Treibs } \\ 8 & \text { R. F. Dickerson } \\ 9 & \text { R. L. Dillon } \\ 10 & \text { R. V. Dulin } \\ 11 & \text { R. J. Fullerton-D. S. Skeie } \\ 12 & \text { B. Griggs } \\ 13 & \text { J. H. Hoage } \\ 14 & \text { D. C. Kaulitz } \\ 15 & \text { W. R. Lewis } \\ 16 & \text { G. W. Mettler } \\ 17 & \text { W. E. Roake-H. J. Anderson } \\ 18-22 & \text { D. W. Shannon } \\ 23 & \text { R. A. Thiede } \\ 24 & \text { E. E. Voiland } \\ 25 & \text { R. G. Wheeler } \\ 26 & \text { R. D. Widrig } \\ 27 & \text { F. W. Woodfield } \\ 28 & \text { H. H. Yoshikawa-G. L. Tingey } \\ 29 & \text { Technical Publications } \\ 30-34 & \text { Technical Information Files } \\ & \end{array}$


EXTERNAL DISTRIBUTION (Special)

Number of Copies

8

General Electric Company, Richland Attn: T. W. Ambrose

J. P. Cooke

D. H. Curtiss

K. L. Fowler

E. A. Grimm

R. E. Hall

M. Lewis

R. A. Rohrbacher

2

Richland Operations Office

Attn: Technical Information Library

R. K. Sharp 
Ptd.
Standard Distribution

ABERDEEN PROVING GROUND

ACF INDUSTRIES, INC.

AEROJET.GENERAL CORPORATION

AEROJET-GENERAL NUCLEONICS

AERONAUTICAL SYSTEMS DIVISIÓN

AIR FORCE INSTITUTE OF TECHISOLOGY

AIR FORCE SURGEON GENERAL

AIR FORCE WEAPONS LABORATORY

ALBUQUERQUE OPERATIONS OFFICE

ALLIS-CHALMERS MANUFACTURING COMPANY

ALLISCHALMERS MANUFACTURING COMPANY. BETHESSOA

ALLISON DIVISION-GMC

ARGONNE CANCER RESEARCH HOSPITAL

ARGONNE NATIONAL LABORATORY

ARMED FORCES RADIOBIOLOGY RESEARCH INSTITUTE

ARMY CHEMICAL RESEARCH AND DEYELOPMENT LABORATORIES

ARMY ELECTRONICS RESEARCH AND DEVELOPMENT LABORATORIES

ARMY ENGINEER RESEARCH AND DEYELOP. MEMT LABORATORIES

ARMY ENYIRONMENTAL HYGIENE AGENCY

ARMY MATERIALS RESEARCH AGENCY

ARMY NUCLEAR DEFENSE LABORATORY

ARMY RESEARCH OFFICE, DURHAM

ARMY TANK-AUTOMOTIVE CENTER

ATOMIC BOMB CASUALTY COMMISSIOH

ATOMIC ENERGY COMMISSION, BETHESDA

AEC SCIENTIFIC REPRESENTATIVE, FRANCE

AEC SCIENTIFIC REPRESENTATIVE, JAPAN

ATOMIC ENERGY COMMISSION, WASHINGTON

ATOMIC ENERGY OF CANADA LIMITED

ATOMIC ENERGY OF CANADA LIMITED, WHITESHELL

ATOMICS INTERNATIONAL

AYCO CORPORATION
Ptd.

2

$\therefore$ i.

1
Standard Distribution

BABCOCK AND WILCOX COMPANY

BATTELLE MEMORIAL INSTITUTE

BERYLLIUM CORPORATION

BROOKHAYEN NATIONAL LABORATORY

BUREAU OF MINES, ALBANY

BUREAU OF MINES, SALT LAKE CITY

BUREAU OF SHIPS (CODE 1500)

CHICAGO PATENT GROUP

COLUMBIA UNIYERSITY (CROPPER)

COMBUSTION ENGINEERING, INC.

COMBUSTION ENGINEERING, INC. (NRD)

COMMITTEE ON THE EFFECTS OF ATOMIC RADIATION

DEFENCE RESEARČH MEMBER

DENVER RESEARCH INSTITUTE

DOW CHEMICAL COMPANY, ROCKY FLATS

DU PONT COMPANY, AIKEN

DU PONT COMPANY, WILMINGTON

EDGERTON, GERMESHAUSEN AND GRIER, INC. GOLETA

EDGERTON, GERMESHAUSEN AND GRIER, INC., LAS VEGAS

FRANKFORD ARSENAL

FULDAMEITTAL METHODS ASSOCIATIOH

GENERAL ATOMIC DIVISION

GENERAL DYMAMICS/FORT WORTH

GENERAL ELECTRIC COMPANY, CINCINNATI

GENERAL ELECTRIC COMPAKY, SAN JOSE

GOODYEAR ATOMIC CORPORATION

HARVARD UNIVERSITY

HAZLETON NUCLEAR SCIENCE CORPORATION

HUGHES AIRCRAFT COMPANY

*INTER-AMERICAN INSTITUTE OF AGRICULTURAL SCIENCES

IOWA STATE UNIVERSITY

JET PROPULSION LABORATORY

JOHNS HOPKINS UNIVERSITY

KNOLLS ATOMIC POWER LABORATORY

LOS ALAMOS SCIENTIFIC LABORATORY

MALLINCKRODT CHEMICAL WORKS 
$\begin{array}{lll}\text { Standard Distribution . . . } & \therefore & \text { Ptd. }\end{array}$

MARE ISLAND NAYAL SHIPYARD

MARITIME ADMINISTRATION

MARTIM-MARIETTA CORPORATION

MASSACHUSETTS INSTITUTE OF TECHNOLOGY

MONSANTO RESEARCH CORPORATION

MOUND LABORATORY

NASA LEWIS.RESEARCH CENTER

MASA MANMED SPACECRAET CENTER

NASA SCIENTIPIC AKD TECHNICAL INFORMATION FACILITY

NATIONAL AGRICULTURAL LIBRARY

NATIONAL BUREAU OF STAMDARDS

NATIONAL BUREAU OF STANDARDS (LIBRARY)

NATIONAL LEAD COMPANY OF OHIO

*NATIONAL REACTOR TESTING STATION (PPCO)

NAYAL MEDICAL RESEARCH INSTITUTE

NAYAL POSTGRADUATE SCHOOL

NAVAL RADIOLOGICAL DEFENSE LABORATORY

NAYAL RESEARCH LABORATORY

NEW BRUNSWICK AREA OFFICE

NEW YORK OPERATIONS OFFICE

NRA, INC.

NUCLEAR MATERIALS AND EQUIPMENT. CORPORATIOH

NUCLEAR METALS, INC.

NUCLEAR SCENCE AND ENGINEERING .CORPORATION

NUCLEAR UTILITY SERVICES, INC.

OFFICE OF ASSISTANT GENERAL COUNSEL FOR PATENTS (AEC)

OFFICE OF HAYAL RESEARCH

OFFICE OF NAYAL RESEARCH (CODE 422)

OFFICE OF THE CHIEF OF RESEARCH AND DEVELOPMENT

POWER REACTOR DEVELOPMENT COMPANY

PRATT AND WHITNEY AIRCRAFT DIVISION

PRINCETON UNIVERSITY (SHERR)
Ptd.
Standard Distribution -

PUBLIC HEALTH SERYICE

PUBLIC HEALTH SER̈VICE, LAS VEGAS

PUBLIC HEALTH SERVICE, MONTGOMERY

PURDUE UNIVERSITY

RADIATION APPLICATIONS, INC.

RADIOPTICS, INC.

RAND CORPORATION

REYNOLDS ELECTRICAL AND ENGINEERING COMPANY, INC.

ROCKY MOUNTAIN ARSENAL

SAMDIA CORPORATION, ALBUQUERQUE

SANDIA CORPORATION, LIYERMORE

SCHOOL OF AEROSPACE MEDICINE

SOUTHWEST RESEARCH INSTITUTE

TRACERLAB, INC., RICHMOND

UNION CARBIDE CORPORATION (ORGDP)

UMION CARBIDE CORPORATION (ORML)

UNION CARBIDE CORPORATION IPADUCAH PLANT)

UNION CARBIDE CORPORATION (TUXEDO)

UNITED NUCLEAR CORPORATION (NDA)

U. S. GEOLOGICAL SURVEY (BAL)

U. S. GEOLOGICAL SURYEY, DENYER

U. S. GEOLUGICAL SURYEY, MENLO PARK

U. S. GEOLOGICAL SURYEY, WASHINGTON

U. S. PATENT OFFICE

UNIVERSITY OF CALIFORNIA, BERKELEY

UNIVERSITY OF CALIFORNIA, LIYERMORE

UNIVERSITY OF CALIFORNIA, LOS ANGELES

UNIVERSITY OF HAWAII

UNIVERSITY OF PUERTO RICO

UNIVERSITY OF ROCHESTER

UNIVERSITY OF UTAH

UNIVERSITY OF WASHINGTON

WALTER REED ARMY MEDICAL CENTER

WESTINGHOUSE BETTIS ATOMIC POWER LABORATORY

WESTINGHOUSE ELECTRIC CORPORATION 
UC-4

CHEMISTRY

Ptd.

285
Standard Distribution (NASA)

DIVISION OF TECHNICAL INFORMATION EXTENSION

WESTINGHOUSE ELECTRIC CORPORATIOM

Ptd.

TW-4500

39 th Ed.

Standard Distribution

*New listing or change in old listing.

'pl' 